\title{
Nutrient removal effectivity of seaweeds as biofilter and water pollution control in hybrid grouper aquaculture wastewater at low salinity
}

Ratih Ida Adharini ( $\square$ ratih.adharini@ugm.ac.id)

Universitas Gadjah Mada https://orcid.org/0000-0001-6966-3097

Murwantoko Murwantoko

Department of Fisheries Faculty of Agriculture Universitas Gadjah Mada

Namastra Probosunu

Department of Fisheries Faculty of Agriculture Universitas Gadjah Mada

Riza Yuliratno Setiawan

Department of Fisheries Faculty of Agriculture Universitas Gadjah Mada

Tony Budi Satriyo

Department of Fisheries Faculty of Agriculture Universitas Gadjah Mada

Research

Keywords: seaweeds, biofilter, hybrid grouper, wastewater, nutrient removal

Posted Date: February 2nd, 2021

DOI: https://doi.org/10.21203/rs.3.rs-149402/v2

License: (9) This work is licensed under a Creative Commons Attribution 4.0 International License.

Read Full License 


\section{Abstract}

This research aims to determine the performance and nutrient removal effectivity of seaweeds species, namely Ulva fasciata., Sargassum illicifolium, Gelidium sp., and Dictyota sp. as a biofilter in hybrid grouper aquaculture wastewater at low salinity (14-17 ppt). This study used a Completely Randomized Design with 3 replications. The statistical analysis was carried out by Analysis of Variance continued with the Least Significance Difference test, and the Kruskal-Walis test with the Mann-Whitney analysis, and T-test with a confidence level of $95 \%$. The concentrations of ammonia, nitrate, phosphate, and water quality parameters were observed every 4 days. The seaweeds uptake of $\mathrm{N}$ and $\mathrm{P}$ in water, and Specific Growth Rate were also observed. The results showed that $U$. fasciata was able to reduce ammonia by $75.95 \%$ and nitrate by $79.53 \%$, which were the highest compared to other treatments, while Dictyota sp. was able to reduce the highest phosphate by $87.5 \%$ for 20 days. The highest SGR was achieved by $U$. fasciata at $1.91 \%$ day $^{-1}$. The highest $\mathrm{N}$ content uptake by seaweeds was $104.4 \%$, and the total $\mathrm{P}$ of $182.3 \%$ occurred in $U$. fasciata. Overall, $U$. fasciata has the highest performance and effectiveness as a biofilter that is able to reduce nutrient waste in low-salinity from grouper aquaculture, for re-circulation or before being discharged into the environment to reduce eutrophication and harmful Algal Blooms (HABs) in aquatic environment. The highest growth rate of $U$. fasciata can be used as food with highly nutritional and economical value.

\section{Background}

The need for animal protein derived from fish is increasing, FAO reported that the world fish consumption was 156 million tonnes in 2018 [1]. Therefore, in order to meet these needs, cultivation efforts are carried out including the groupers' species. The Indonesian government increases grouper cultivation to meet the domestic and export demand, as well as reduce natural catchment to maintain its sustainability. The Indonesian Ministry of Maritime Affairs and Fisheries reported that, there has been an increase of this species in 2012 by 11,950 tons to 70,294 tons in 2017. Grouper is a hybrid fish (Epinephellus fuscoguttatus-lanceolatus), widely cultivated because of its fast growth, high tolerance for salinity [2;3], and relatively resistant to disease [4]. Furthermore, it can be cultivated in the highlands (393 $\mathrm{m}$ above sea level) far from the coast, at a relatively low salinity of around 14-17 ppt.

However, the increasing grouper culture without proper waste management before being discharged into open water cause eutrophication, due to the accumulation of leftover feed and faeces. The use of "pellet" feed in intensive modern cultivation has created new problems in the waters [5], such as triggering eutrophication, due to the input of excessive nitogen and phosphorus into the water, which leads to harmful algal blooms (HABs). HABs threaten biodiversity, habitat loss, and increase the harmful algal blooms' frequency [6], as well as having impact on the social, economic, and health of coastal communities. The ingrated multi-trophic aquaculture (IMTA) is an effort to overcome this problem through the use of seaweeds as an inorganic extractive species [7;8]. Seaweeds biofilter is the most 
preferred wastewater treatment technology in marine fish aquaculture, because it is eco-friendly, abundantly available, and cheap [9]. Therefore, it is important to sellect appropriate seaweeds as inorganic extractive species for reducing nutrient wastewater, increasing water quality and fish growth.

Seaweed utilization in biofilter and bioremediator have been widely studied, such as Ulva, Palmaria palmata, Gracilaria, Kappaphycus, and Hypnea aspera $[8 ; 10 ; 11 ; 12 ; 13 ; 14 ; 15 ; 16 ; 17 ; 18 ; 19 ; 20]$. Seaweeds are reported to have the ability to reduce nutrients in water. However, their activity in IMTA as an inorganic extractive species must be considered its suitability between the main commodity (finfish), and the environmental conditions of the aquaculture. Besides, the effectivity as biofilter of each species is different capability [19], dependent on volume and circulation of water, initial biomass, water quality and the physiology of each seaweeds [20]. This is because each seaweeds has different tolerance for life suitability, therefore, it affecting its ability to carry out nutrient removal, life survival, and growth process.

Therefore, the hybrid grouper aquaculture which cultivated in the highlands at a salinity of 14-17 ppt, also requires appropriate seaweeds as a biofilter that able to tolerate these water conditions, and works efficiently. This research aims to determine the most effective species of Ulva fasciata, Sargassum illicifolium, Gelidium sp., and Dictyota $s p$. as biofilter in hybrid grouper cultivation at low salinity. The result of this research is expected as a method to reduce nutrient wastewater, so it can be used for recirculating water, and reducing eutrophication in open water system.

\section{Materials And Methods}

\section{Collection and acclimation}

Seaweed species of U. fasciata., Chaetomorpha sp., Caulerpa sp., S. illicifolium, Padina sp., Gracilaria sp., Gelidium sp., and Dictyota sp. were collected from the intertidal area of Tenggole Beach, Gunungkidul, Yogyakarta. Then cleaned of any attached animals and epiphytes. The acclimation process was carried out in stages, from the salinity of $30 \mathrm{ppt}$, continued with $25 \mathrm{ppt}$, then 20 and $15 \mathrm{ppt}$ for 3 days, respectively. This process was performed because the grouper culture wastewater has a salinity of 14-17 ppt, then the water quality was observed and aerated in the closed system. After the acclimation process, only U. fasciata, S. illicifolium, Gelidium sp., and Dictyota sp. survived, therefore, these four species were used for the main test.

\section{Main Test}

Wastewater from grouper culture was obtained from hybrid grouper farm which is cultivated in mountainous areas (393m height above sea level), and then soaked in 15 aquariums which each volume was $15 \mathrm{~L}$. Every treatments used $3 \mathrm{~g} \mathrm{~L}^{-1}$ of each seaweeds that has been acclimated before was tested as biofilter in grouper culture wastewater, in a closed system with aeration to determine its performance and effectiveness to remove nutrients wastewater for 20 days. The treatments consisted of P0 (Control), P1 (U. fasciata), P2 (S. illicifolium), P3 (Gelidium sp.), and P4 (Dictyota sp.). Water quality parameters were observed using water quality checker including temperature, $\mathrm{pH}$, salinity, Total Dissolved Solid (5 in 1 
meter, PH-9909) and Dissolved Oxygen (DO Meter Lutron-5519). Total Suspended Solids (TSS) was calculated by filtration method using Whatman GF / C filter paper, and then compared between initial and final weight. Ammonia, Nitrate, and Phosphate contents were tested using the Visicolour ECO test kit method and a Compact photometer PF-12. Nutrient uptake efficiency was calculated using the following formula :

Nutrient removal effectivity in water $(\%)=\frac{\text { Water } N 0-\text { Water } N t}{\text { Water } N 0} \times 100$

Total $\mathrm{N}$ content in seaweed was tested using the Kjeldahl method, while for total $\mathrm{P}$ with the Spectrophotometry method.

The absorption of $\mathrm{N}$ and $\mathrm{P}$ by seaweed is assumed by the percentage of $\mathrm{N}$ and $\mathrm{P}$ added in the seaweed thallus with the following formula:

Addition of $\mathrm{N}$ or $\mathrm{P}$ in thallus $(\%)=\frac{C f-C i}{C i} \times 100$

Where $\mathrm{Cf}$ and $\mathrm{Ci}=$ final and initial concentration

Specific growth rate (SGR) seaweeds was calculated using the formula :

SGR $\left(\%\right.$ day $\left.^{-1}\right)=\left[\left(\ln W_{-}-\ln W i\right) / t\right] \times 100 \%$

Where $\mathrm{Wf}$ and $\mathrm{Wi}=$ final and initial weight, $\mathrm{t}$ is period of time.

\section{Statistical Analysis}

The data collected were analyzed using SPSS (Statistical Package for the Social Sciences) version 18.0. The statistical analysis was conducted by performing the normality and homogeneity test to determine the parametric or non-parametric statistical assessment. Furthermore, the ANOVA test was used to observe the significant difference between the treatments in each water quality parameter, for the data that was normally distributed and homogeneous was tested using the LSD (Least Significant Difference) analysis. While, the data that were not normally distributed and not homogeneous was tested using the Kruskal- Walis analysis with further T-test or Mann-Whitney test. A confidence level of $95 \%(a=0.05)$ was used for all statistical tests.

\section{Result}




\subsection{Water Quality Parameter}

The water quality parameter during the experiments with four different species as biofilter of hybrid grouper aquaculture wastewater was shown in table 1. Water temperature, salinity, Total Dissolved Solid (TDS), and Total Suspended Solid (TSS) showed no significant difference. Water temperature ranges from $27-29^{\circ} \mathrm{C}$ during the experiment. The overall salinity gradually increased from 14 to $17 \mathrm{ppt}$, due to the evaporation, also with TDS. The TSS showed the lowest decrease $\left(0.38-0.66 \mathrm{mgL}^{-1}\right)$ on day $8^{\text {th }}$ from $2.53 \pm 0.11 \mathrm{mgL}^{-1}$ on day- 0 .

Table 1. Water quality parameter during experiments with four different species as biofilter of hybrid grouper aquaculture wastewater

\begin{tabular}{lllllll}
\hline Treatment & \multicolumn{5}{c}{ Parameter } \\
\cline { 2 - 7 } & $\begin{array}{l}\text { Temp. } \\
\left({ }^{\circ} \mathrm{C}\right)\end{array}$ & $\begin{array}{l}\text { Salinity } \\
\text { (ppt) }\end{array}$ & $\mathrm{pH}$ & $\mathrm{DO}$ & $\begin{array}{l}\text { TSS } \\
(\mathrm{mpm})\end{array}$ & TDS \\
\hline P0 (Control) & $27-29$ & $14,4-16,4$ & $7,2-8,2$ & $3,2-9,8$ & $0,23-2,53$ & $16,43-18,13$ \\
P1 (U. fasciata) & $27-29$ & $14,3-14,4$ & $7,3-8,2$ & $3,3-11,6$ & $0,20-2,37$ & $16,23-18,57$ \\
P2 (S. ilicifolium)27-29 & $14,4-16,2$ & $7,1-8,1$ & $2,6-10,5$ & $0,32-2,57$ & $16,30-18,17$ \\
P3 (Gelidium sp.)27-29 & $14,5-16,6$ & $7,2-7,9$ & $2,9-10,1$ & $0,17-2,67$ & $16,00-18,50$ \\
P4 (Dictyota sp.) 27-29 & $14,5-16,6$ & $7,3-8,3$ & $3,1-11$ & $0,36-2,59$ & $16,13-18,43$ \\
\hline
\end{tabular}

The dissolved oxygen and $\mathrm{pH}$ showed significant differences between treatments. The dissolved oxygen in all treatments after day $4^{\text {th }}$ showed decreasing to $3 \mathrm{mgL}^{-1}$, this was caused by the activity of bacteria to decompose wastewater that needed oxygen. This DO concentration then increased after the $4^{\text {th }}$ day. The highest DO occurred on the $12^{\text {th }}$ day of treatment with $U$. fasciata until it reached $11.37 \mathrm{mgL}^{-1}$ that indicating a significant difference from others. After increasing on days $12^{\text {th }}$ and $16^{\text {th }}$, the DO decreased to an average of $6.1 \mathrm{mgL}^{-1}$ on day $20^{\text {th }}$ (Fig. 1a.).

\subsection{Nutrient Removal}

The concentration of ammonia in wastewater with $U$. fasciata treatment on day $4^{\text {th }}$ was successfully reduced to $0.57 \pm 0.04 \mathrm{mgL}^{-1}(63.92 \%)$, which was the lowest compared to others. In all treatments, there was an increase in ammonia on the day $16^{\text {th }}$, and then decreasing on the day $20^{\text {th }}$ until $73.88 \%$ (Fig. 2a).

The concentration of nitrate in water in the $U$. fasciata treatment increased until day $4^{\text {th }}$, and then consistently decreased until it reached $1.47 \pm 0.3 \mathrm{mgL}^{-1}$, or reduced the nitrate by $79.49 \%$ on day $20^{\text {th }}$. Meanwhile, other treatments showed that the increase in nitrate concentration occurred up to day $8^{\text {th }}$ (Fig. 
2b). This increase occurred because, ammonia at that time was still experiencing a change to become ammonium, nitrite, and nitrate which took a certain time because it was influenced by environmental factors, such as temperature, $\mathrm{pH}$, and dissolved oxygen.

Phosphate concentration during treatment showed a consistent decreasing until the $20^{\text {th }}$ day. However, Dictyota sp. showed the fastest decreasing in phosphate concentration on day $12^{\text {th }}$ that reached $0.73 \pm$ $0.09 \mathrm{mgL}^{-1}(81.75 \%)$, and the lowest was $0.50 \pm 0.06 \mathrm{mgL}^{-1}$ (87.50\%). Meanwhile, U. fasciata, Gelidium sp., and S. illicifolium were able to reduce phosphate concentrations by $83.05 \%, 75.61 \%$, and $70.27 \%$ on the $20^{\text {th }}$ day, respectively (Fig. 2c).

The largest percentage of ammonia reduction in water was shown by the treatment of $U$. fasciata, followed by S. illicifolium, Gelidium sp. and Dictyota sp. However, the percentage reduction of ammonia in the water showed no significant difference in all the treatments. The highest percentage of nitrate reduction in water was shown in the treatment of $U$. fasciata that can reduce nitrate $79.53 \%$, although it was not significantly different with S. illicifolium and Gelidium sp.. Furthermore, the largest percentage reduction in phosphate was shown by Dictyota $s p$. That can reduce phosphate until $87.50 \%$. Eventhough it was not significantly different with U. fasciata (83.05\%), however it was significantly different from the control, S. illicifolium, and Dictyota sp (Figure 3.)

\subsection{Content of $N$ total and $P$ total in thallus}

Figure 4 showed that the percentage of the total $\mathrm{P}$ content addition in thallus seaweed tends to be higher than that of total $\mathrm{N}$ content. Overall, $U$. fasciata has the most effective absorption of $\mathrm{N}$ and $\mathrm{P}$ in wastewater because it has the highest addition of total $\mathrm{N}$ and $\mathrm{P}$ contents in thallus. Meanwhile, Gelidium sp. has the lowest $\mathrm{N}$ and $\mathrm{P}$ absorption compared to U. fasciata, Dictyota sp., and S. illicifolium.

\subsection{Specific growth rate (SGR)}

U. fasciata has the best growth rate at $1.91 \%$ day $^{-1}$, followed by Dictyota sp at $0.36 \%$ day $^{-1}$, and Gelidium sp at $0.25 \%$ day $^{-1}$. While S. illicifolium has the lowest SGR $-1.71 \%$ day $^{-1}$ (Figure 5) because some thalli were fragmented, therefore effect on the final weight of seaweed .

\section{Discussion}

Treatments that used $U$. fasciata and Dictyota sp. has a relatively higher DO than the control, because the these species have a better metabolism, survival, and photosynthesis process, which then increased DO and reduced the dissolved carbon dioxide in aquaculture wastewater. Meanwhile, the DO concentration with S. illicifolium and Gelidium sp. Treatments were lower than the control, because the metabolic process was disrupted to adapt to the conditions of wastewater quality, therefore the photosynthesis process was not optimal. U. fasciata and Dictyota sp., which were able to increase DO than other treatments, also showed a tendency to have higher in pH (Fig. 1b). This was happened because these seaweed was able to produce $\mathrm{DO}$ so that increase water $\mathrm{pH}$, while concentration of dissoved $\mathrm{CO}_{2}$ which 
causes acidity tend to decrease in water [21]. Therefore, U. fasciata and Dictyota sp. have capability to balance the $\mathrm{pH}$ in acidic water conditions, which are less favorable for aquatic organisms.

The increasing of ammonia occured until day $16^{\text {th }}$, it might be caused that on the $16^{\text {th }}$ day the process of converting ammonia to ammonium and nitrate was disrupted due to a decrease in water temperature which reduces the ability of nitrifying bacteria to decompose ammonia. This was reinforced by [22] that nitrogen uptake is efficient and reaches its maximum in summer when air and water temperatures increase. Also, the ability of nutrient uptake by the biofilter was influenced by temperature and water exchange rate at various environmental conditions [23]. Biofilter treatment using $U$. fasciata showed significantly different results compared to other treatments (control; S. illicifolium; Gelidium sp.; and Dictyota sp.). Meanwhile, $U$. fasciata showed the most efficient performance to reduce nitrate from day $4^{\text {th }}$, while other seaweeds treatments indicated a decrease after day $8^{\text {th }}$. The same result was also shown by [24], which stated that Ulva spp was able to reduce nutrients in the form of nitrogen more efficiently than Gracilaria birdiae. This decrease in nitrate concentration indicated that the nitrate in the water has been absorbed by seaweeds, which role as nutrient removal. Ulva absorbs dissolved inorganic nitrogen for less than 1 hour and stores nitrate as an internal reserve in the thallus [15].

The addition of the total $\mathrm{N}$ and $\mathrm{P}$ content in seaweed thallus was assumed as its ability to absorb or remove nutrients in the water. Therefore, the greater percentation of the total $\mathrm{N}$ and $\mathrm{P}$ addition, the more effective the seaweed in absorbing and utilizing these nutrients for metabolism and growth. The highest percentage of the total $\mathrm{N}$ addition was shown by $U$. fasciata (104.4\%), while the lowest was indicated by Gelidium sp. (2,6\%). The high concentrations of ammonium and nitrate in water trigger an increase in the accumulation of total dissolved protein [18]. Therefore the nitrogen content in the thallus of Hypnea Aspera also increased, even though not all absorbed nutrients were assimilated and stored. This was because all nitrates and ammonium returned to the water in other forms. The percentage of the total $P$ content addition, tends to be higher than that of total $\mathrm{N}$ content addition to thallus seaweed. This is occurred because the concentration of phosphate in water was higher than that of ammonia. Therefore, the phosphate absorbtion was higher than the nitrate. The highest percentage of total $\mathrm{P}$ content addition of the thallus was found in U. fasciata (182.3\%), while the lowest was in the Gelidium sp. (9.3\%). However, not all absorbed inorganic phosphate was used for growth, also, it increase the concentration of pigments, protein, and phosphorus in the thallus [18].

1. fasciata has the highest Specific Growth Rate because it has the best ability to deal with unfavorable wastewater conditions. This was in accordance with the statement that Ulva has a high tolerance and good environmental adaptability, to fluctuations in irradiance, temperature, salinity, and drying $[24 ; 25]$. This was also confirmed by [26] which stated that Ulva survives in low salinity conditions. Furthermore, during this study U. fasciata also has the highest ability to absorb nutrients compared to other seaweeds, and is able to utilize these absorbed nutrients for metabolic processes properly, therefore it has the highest of Specific Growth Rate (SGR) than other treatments. S. illicifolium has the lowest SGR because some parts of the thallus had died, which was characterized by the thalus being easily fragmented and flabby that affect on the final weight and SGR. Temperature and salinity 
are environmental limiting factors that affect the growth, carbon, and nitrogen content of the thallus [27]. S. illicifolium during this study was unable to withstand with the conditions of low salinity, consequently became non efficient in absorbing nutrients, and resulted death in some parts of thallus. Some tips of Gelidium thalli also became green, while some tips of Dictyota sp. thalli also became pale and fragile. This change in colour to a pale whitish is often referred to as ice-ice disease, which is triggered by stress in aquatic environmental conditions that are not in accordance with the tolerance for its life. Therefore, in this case, some tips of Dictyota sp. thalli were stricken with ice-ice disease, and fragmented because they were unable to tolerate the condition of hybrid grouper wastewater. The salinity of hybrid grouper wastewater tended to be low (14-17 ppt), while naturally Gelidium, Dictyota, and Sargassum inhabit in salinity waters above $25 \mathrm{ppt}$. This condition impact in the life survival, therefore, it was easily infected by viruses and bacteria which further the thallus health became worse. Some parts of the thallus that experienced the ice-ice disease are usually followed by the attachment of epiphytes, which are green moss that sticks to the dead white surface of the thallus. The same incident also occurred in Gracilaria chilencis which infected with filamentous algae when tested in the IMTA system with red abalone [28]. Meanwhile, U. fasciata did not show any epiphytic infection. Therefore, $U$. fasciata was able to grow optimally and did more efficient in absorbing nutrients than S. illicifolium, Gelidium sp., and Dictyota sp..

\section{Conclusion}

Ulva fasciata is the most effective biofilter for the nutrient removal from wastewater grouper aquaculture compared to S. illicifolium, Gelidium sp, and Dictyota sp.. U. fasciata shows the best and most efficient performance as a biofilter, besides easily to obtain, more tolerate with various conditions, resistant to epiphytic attack, and also has a high growth rate. Therefore, $U$. fasciata become a promise candidate species that can be integrated in IMTA system to realize sustainable environmentally friendly fisheries, and as a water pollution control in the open water system to reduce eutrophication.

\section{Declarations}

\section{Availability of data and materials}

The authors declared that the data and materials in this manuscripts are not publicly available due to originality reasons but are available from the corresponding author on reasonable request.

\section{Conflict of Interest}

The authors declare that they have no competing interests

\section{Funding Information}

This research is funded by the Indonesian Ministry of Research, Technology and Higher Education, in the research grant of PDUPT 2020 through Universitas Gadjah Mada. 


\section{Authors' Contributions}

For authors contribution : RIA conducted and coordinated all the research and publication; M and NP arranged the research flow and conducted the research; TBS and RYS analyzed and interpreted data

\section{Acknowledgements}

The authors are grateful to the PT. INDMIRA for their support towards the success of this research.

\section{References}

1. FAO. The state of World Fisheries and Aquaculture, Sustainability in action. Rome. 2020; https://doi.org/10.4060/ca9229en.

2. De M, Ghaffar MA, Das SK. Temperature effect on gastric emptying time of hybrid grouper (Epinephelus spp.). AIP Conf Pros. 2014; 1614: 616-618.

3. Liang HF, Huang DK, Wu YH, Wang CQ, Zhong WJ. Effects of temperature and salinity on survival and food intake of grouper hybrid (Epinephelus lanceolatus x E. fuscoguttatus). Journal of Guangdong Ocean University. 2013; 33: 22-26.

4. Anita NS, Dewi NN. Evaluation of hatching rate, growth performance, and survival rate of cantang grouper (Epinephelus fuscoguttatus x lanceolatus) in concrete pond at Situbondo, East Java, Indonesia. IOP Conf Series: Earth and Environ Sci. 2019; 441: 012019.

5. Edwards P. Aquaculture environment interactions: Past, present and likely future trends. Aquaculture. 2015; 447: 2-14.

6. Fan X, Xu D, Wang D, Wang Y, Zhang X, Ye N. Nutrient uptake and transporter gene expression of ammonium, nitrate, and phosphorus in Ulva linza: adaptation to variable concentrations and temperatures. J. Appl Phycol. 2020; 32: 1311-1322.

7. Troell M, Joyce A, Chopin T, Neori A, Buschmann AH, Fang JG. Ecological engineering in aquaculture - Potential for integrated multi-trophic aquaculture (IMTA) in marine offshore systems. Aquaculture. 2009; 297: 1-9.

8. Laramore S, Baptiste R, Wills PS, Hanisak MD. Utilization of IMTA-produced Ulva lactuca to supplement or partially replaced pelleted diests in shrimps (Litopenaeus vannamei) reared in a clear water production system. J Appl Phycol. 2018; 30: 3603-3610.

9. Arumugam N, Chelliapan S, Kamyab H, Thirugnana S, Othman N, Nasri NS. Treatment of wastewater using seaweed: A Revie. Int J Environ Res Public Health. 2018; 15, 2851:10.3390/ijerph15122851.

10. Tremblay-Gratton A, Boussin JC, Tamigneaux E, Vandenberg GW, Le Francois NR. Bioremediation efficiency of Palmaria palmata and Ulva lactuca for use in a fully resirculated cold-seawater naturalistic exhibit: effect of high $\mathrm{NO}_{3}$ and $\mathrm{PO}_{4}$ concentrations and temperature on growth and nutrient uptake. J Appl Phycol. 2018; 30: 1295-1304. 
11. Neori A, Msuya FE, Shauli L, Schuenhoff A, Shpigel M. A novel three-stage seaweed (Ulva lactucai) biofilter design for integrated mariculture. J Appl Phycol. 2003; 15: 543-553.

12. Mariano-Soriano E, Nunes SO, Carneiro MAA, Pereira DC (2009) Nutrient' removal from aquaculture wastewater using the macroalgae Gracilaria birdiaei. Biomass and Bioenergy 33: 327-331.

13. Andayani S, Yuwanita R, Izzah N. Biofilter application using seaweed (Gracilaria verrucosa) to increase production of Vannamei Shrimp in Traditional Pond District Bangil-Pasuruan. Res J Life Sci. 2016; (3)1: 16-22.

14. Adharini RI, Trianti CM. The utilization of Gracilarua verrucosa as shrimp ponds wastewater biofilter. E3S Web of Conferences. 2020; 147: 02023

15. Anibal J, Madeira HT, Carvalho LF, Esteves E, Veiga-Pires C, Rocha C. Macroalgae mitigation potential for fish aquaculture effluents: an approach coupling nitrogen uptake and metabolic pathways using Ulva rigida and Enteromorpha clathrata. Environ Sci Poll Res. 2013; 21(23): 13324-13334.

16. Carneiro MAA, Freire FAM, Marinho-Soriano E. Study on biofiltration capacity and kinetics of nutrient uptake by Gracilaria cervicornis (Turner) J. Agardh (Rhodophyta, Gracilariaceae). Brazilian J. Pharmacog. 2011; 21(2): 329-333.

17. Elizondo-González R, Quiroz-Gusmán E, Escobedo-Fregoso C, Magallón-Servín P, Peña-Rodríguez A. Use of seaweed Ulva lactuca for water bioremediation and as feed additive for white shrimp Litopenaeus vannamei. Peerk. 2018; 6:e4459, DOI 10.7717/peerj.4459

18. Ribeiro ALNL, Chiozzini VG, Braga ES, Yokoya NS. Physiological responses and biofilter potential of Hypnea aspera (Rhodophyta, Gigartinales) cultivated in different availabilities of nitrate, ammonium, and phosphate. J Appl Phycol. 2017; 29:683-694.

19. Kang YH, Park SR, Chung IK. Biofiltration efficiency and biochemical composition of three seaweed species cultivated in a fish-seaweed integrated culture. Algae. 2011; 26(1):97-108.

20. Hayashi L, Yokoya NS, Ostini S, Pereira RTL, Braga ES, Oliveira EC. Nutrients removed by Kappaphycus alvarezii (Rhodophyta, Solieriaceae) in integrated cultivation with fishes in recirculating water. Aquaculture. 2008; 277:185-191.

21. Schuenhoff A, Shpigel M, Lupatsch I, Ashkenazi A, Msuya FE, Neori A. A semi-resirculating, integrated system for the culture of fish and seaweed. Aquaculture. 2003; 221: 167-181.

22. Matos J, Costa S, Rodrigues A, Pereira R, Pinto IS. Experimental integrated aquaculture of fish and red seaweeds in Northern Portugal. Aquaculture. 2006; 252:31-42.

23. Abreu M, Pereira R, Yarish C, Buschmann AH, Sousa-Pinto I. IMTA with Gracilaria vermiculophylla: productivity and nutrient removal performance of the seaweed in a land-based pilot scale system. Aquaculture. 2011; 312:77-87.

24. Castellar B, Pontes MD, Costa WdM, Moura LCF, Dias GE, Landuci FS, Reis RP. Biofiltering efficiency and productive performance of macroalgae with potential for integrated multi-trophic aquaculture (IMTA). Bol Inst Pesca Sao Paulo. 2015; 41: 763-770.

25. Mantri VA, Kazi MA, Balar NJ, Gupta V, Gajaria T. Concise review of green algal genus Ulva Linnaeus. J Appl Phycol. 2020; 32: 2725-2741. 
26. Tsagkamilis $P$, Danielidies $D$, Dring MJ, Katsaros $C$. Removal of phosphate by the green seaweed Ulva lactuca in a small-scale sewage treatment plant (Ios Island, Aegean Sea, Greece). J Appl Phycol. 2010; 22:331-339.

27. Li J, Liu Y, Liu Y, Wang Q, Gao X, Gong Q. Effects of temperature and salinity on the growth and biochemical composition of the brown alga Sargassum fusiforme (Fucales, Phaeophyceae). J Appl Phycol. 2019; 31: 3061-3068.

28. Macchiavello $\mathrm{J}$ and Bulboa C. Nutrient uptake efficiency of Gracilaria chilensis and Ulva lactuca in an IMTA system with the red abalone Haliotis rufescens. Lat Am J Aquat Res. 2014; 42(3): 523-253.

\section{Figures}


(a)

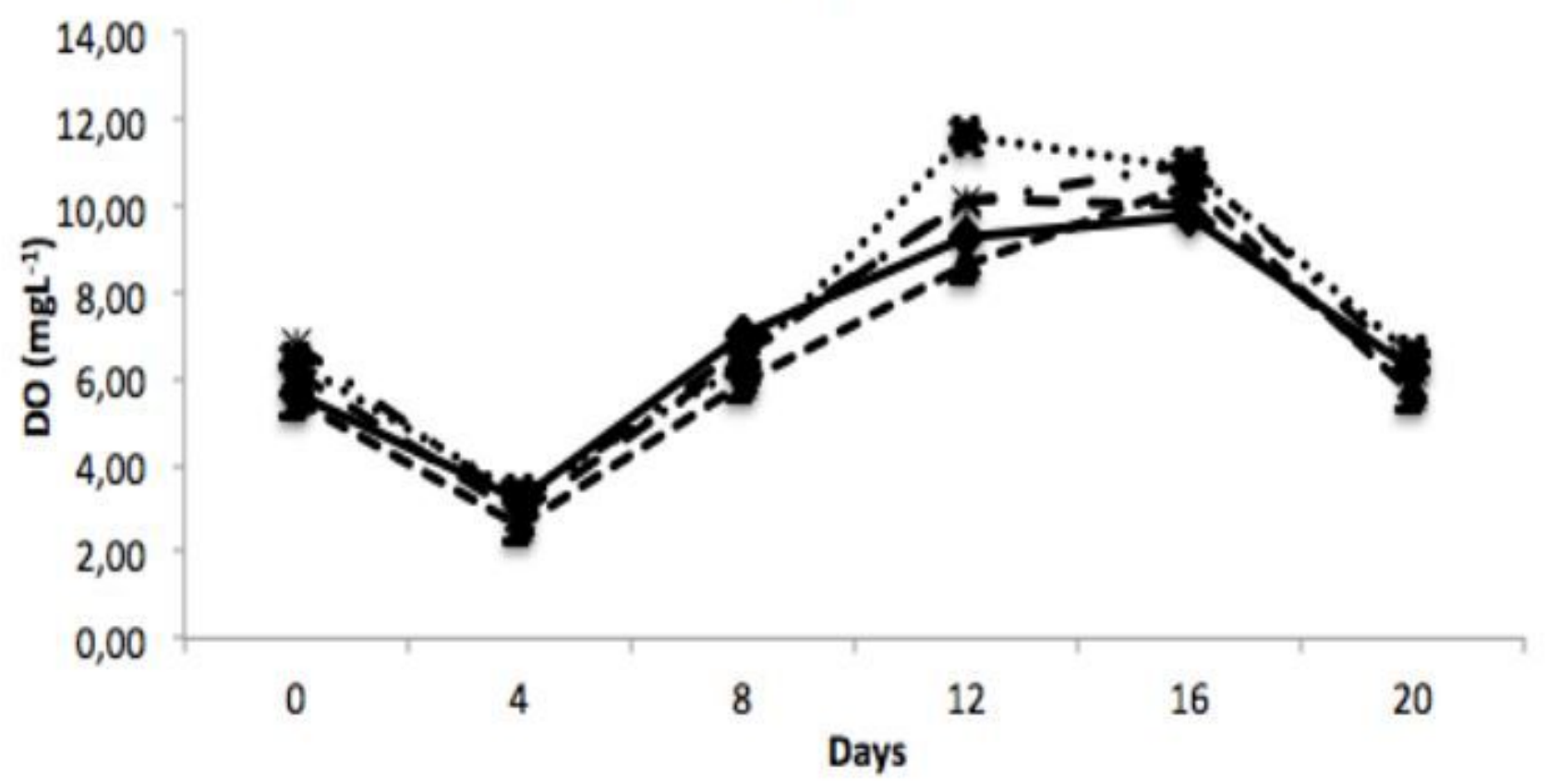

(b)

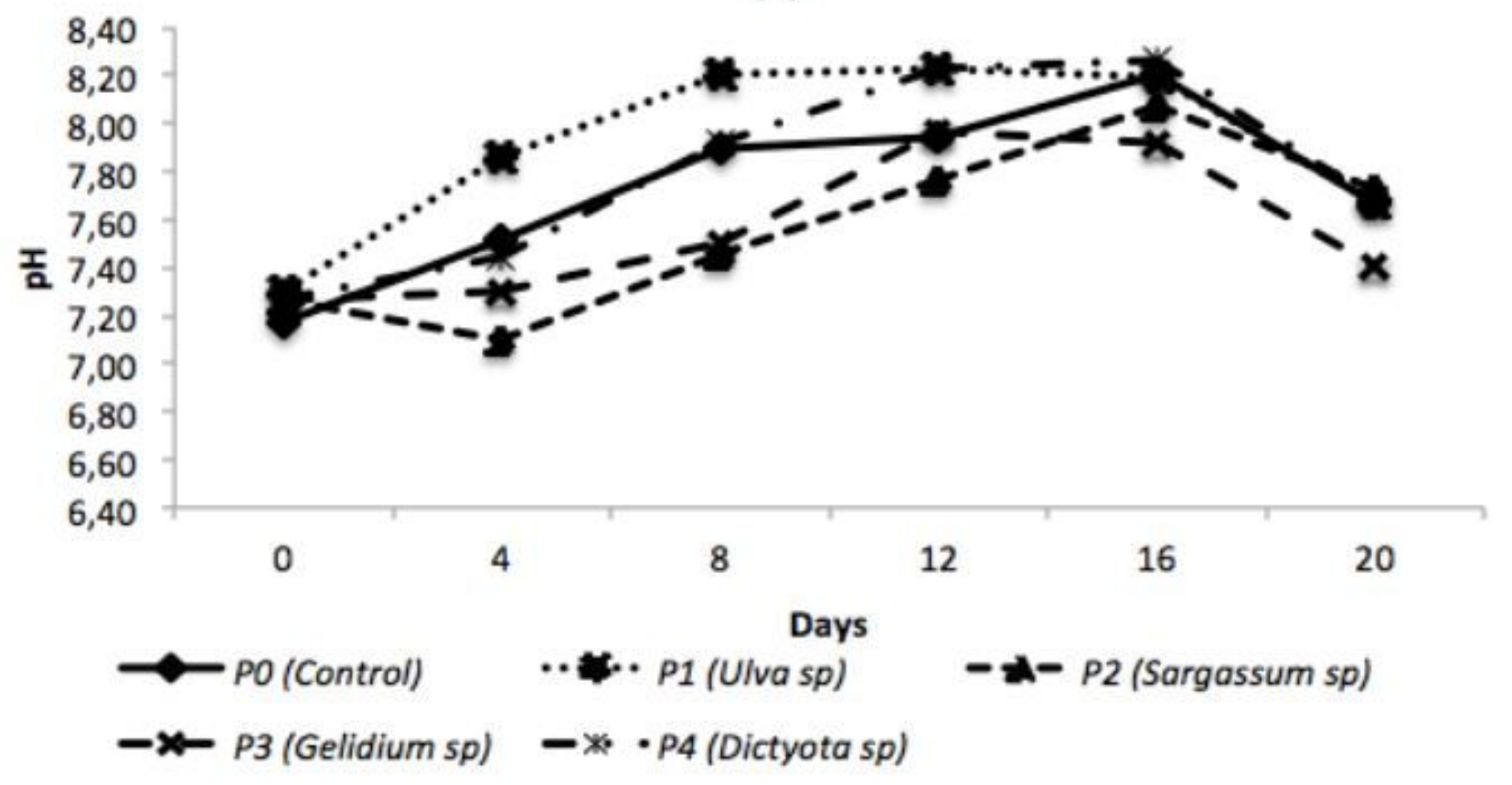

Figure 1

Dynamic of (a) pH and (b) Dissolved Oxygen during experiments with four different seaweeds as biofilter of hybrid grouper aquaculture wastewater in low salinity 


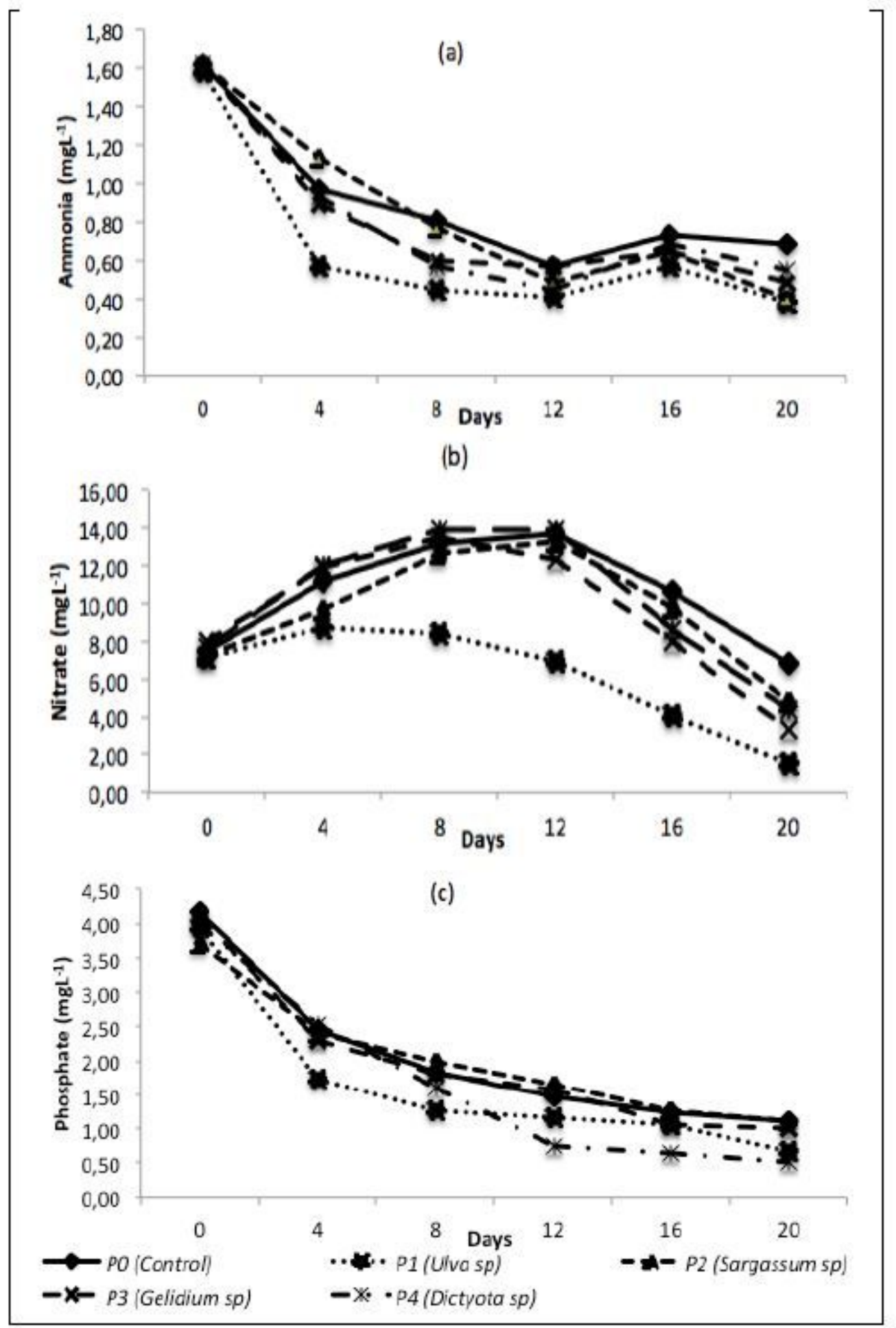

Figure 2

The dynamical of (a) Amonia (NH3), (b) Nitrate (NO3-), and (c) Phosphate (PO43-) concentration during experiment with four different seaweeds as biofilter of hybrid grouper aquaculture wastewater in low salinity. 


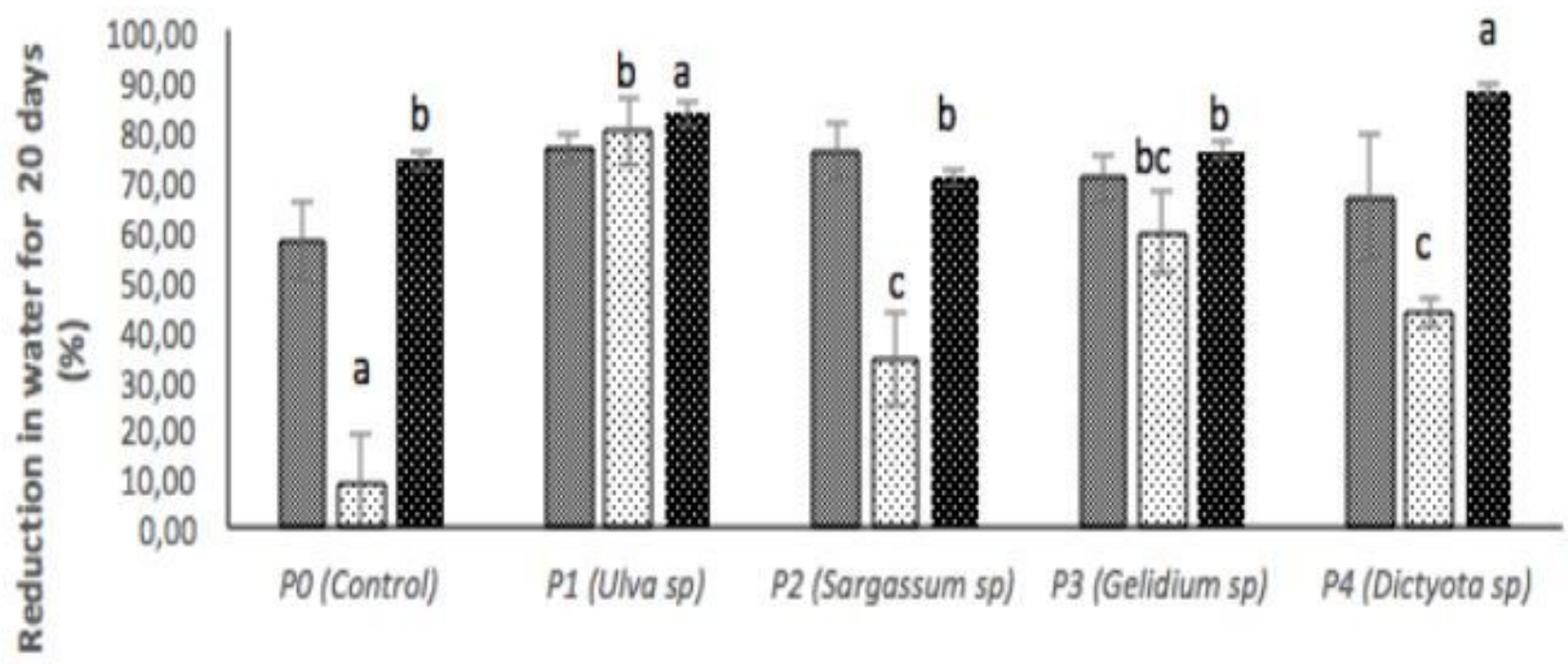

IAMONIA QNITRAT PHOSPHAT

Figure 3

Reduction of Amonia (NH3); Nitrate (NO3-); Phosphate (PO43-) in water for twenty days with four different species as biofilter for hybrid grouper aquaculture wastewater in low salinity

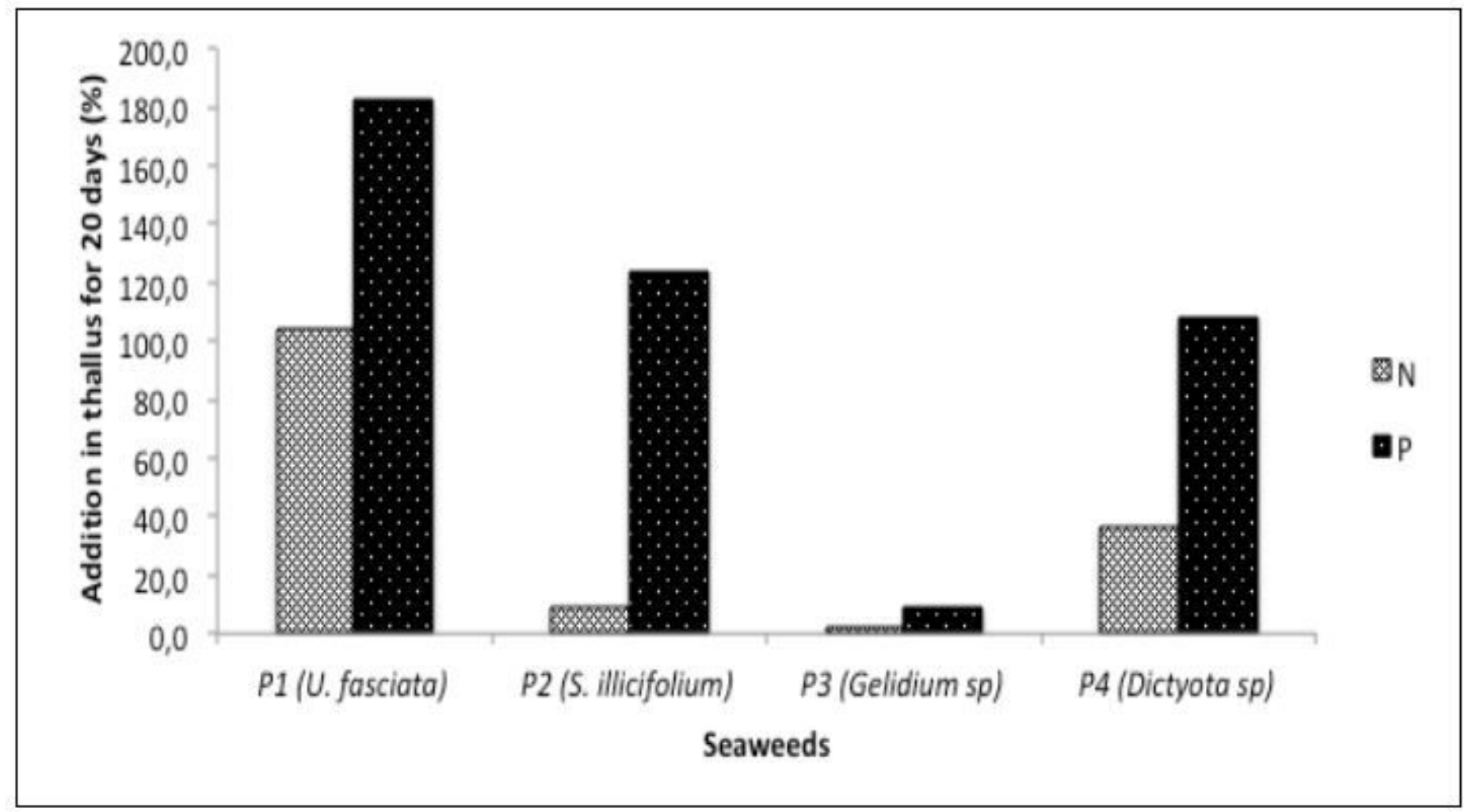

Figure 4 
Percent addition of total $\mathrm{N}$ and $\mathrm{P}$ contents in different thallus of seaweed, for twenty days as biofilter for hybrid grouper aquaculture wastewater in low salinity.

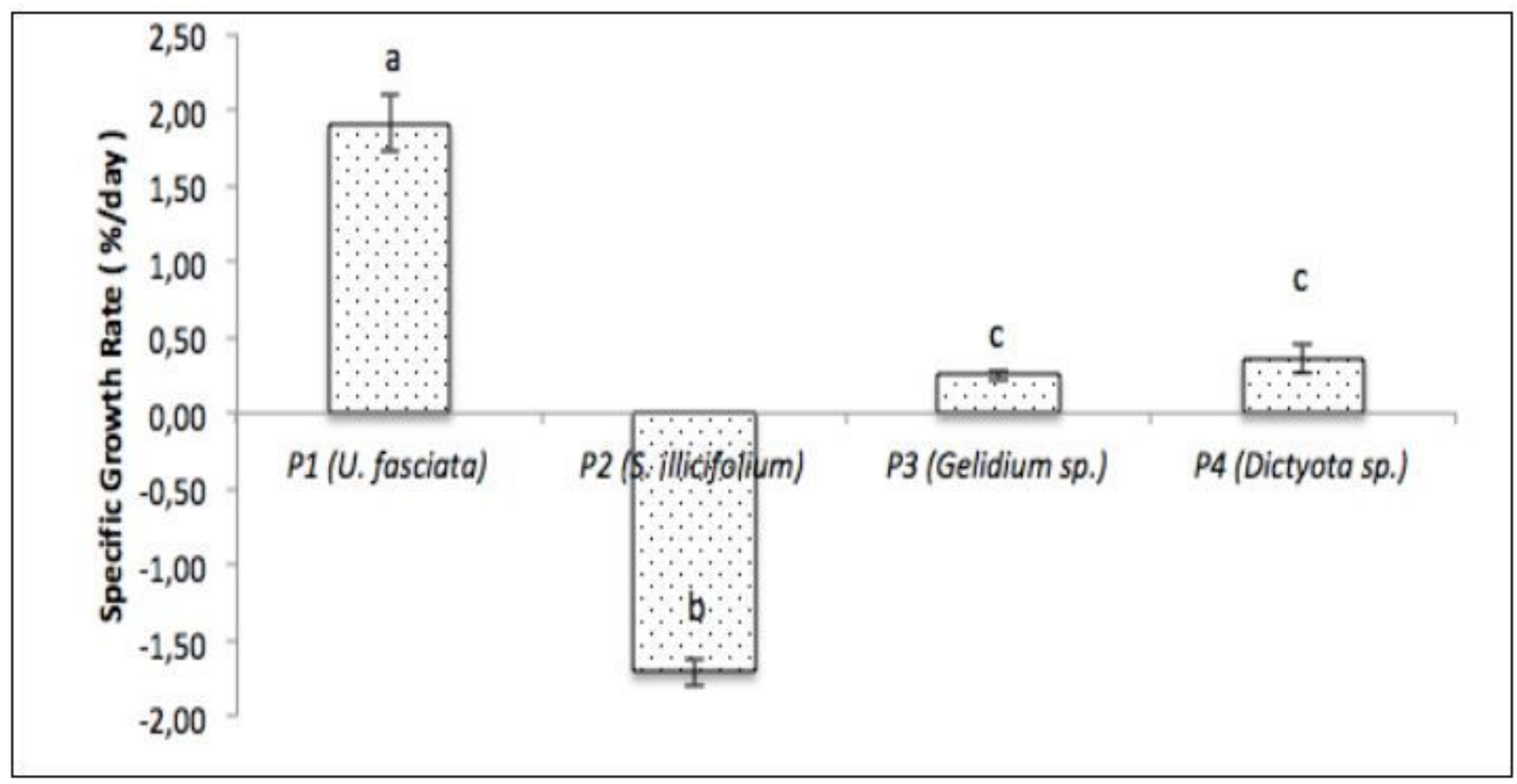

Figure 5

Specific Growth Rate (SGR) of different seaweeds in twenty days as biofilter of hybrid grouper aquaculture wastewater in low salinity. 